\title{
Mollusk bycatch in trawl fisheries targeting the Atlantic seabob shrimp Xiphopenaeus kroyeri on the coast of Sergipe, northeastern Brazil
}

\author{
Luana Marina de Castro Mendonça ${ }^{1,2,6}$; Carmen Regina Parisotto Guimarães ${ }^{2,7}$ \& Silvio Felipe Barbosa Lima ${ }^{3,4,5,8}$
}

1 Universidade Federal do Paraná (UFPR), Departamento de Zoologia (DZO0), Laboratório de Estudos de Cnidaria e Bry0zoa (LECB). Curitiba, PR, Brasil.

2 Universidade Federal de Sergipe (UFS), Centro de Ciências Biológicas e da Saúde (CCBS), Departamento de Biologia (DBI), Laboratório de Bentos Costeiro (LABEC). São Cristóvão, SE, Brasil.

${ }^{3}$ Universidade Federal de Campina Grande (UFCG), Centro de Formação de Professores (CFP), Unidade Acadêmica de Ciências Exatas e da Natureza (UACEN). Cajazeiras, PB, Brasil.

${ }^{4}$ Universidade Federal da Paraíba (UFPB), Centro de Ciências Exatas e da Natureza (CCEN), Departamento de Sistemática e Ecologia (DSE), Programa de Pós-Graduação em Ciências Biológicas (Zoologia). João Pessoa, PB, Brasil.

${ }^{5}$ Universidade Federal da Paraíba (UFPB), Centro de Ciências Agrárias (CCA), Departamento de Ciências Biológicas (DCB), Programa de Pós-Graduação em Biodiversidade. Areia, PB, Brasil.

${ }^{6}$ ORCID: http://orcid.org/0000-0002-0302-4046. E-mail: luana.biologia@yahoo.com.br

7 ORCID: http://orcid.org/0000-0003-1996-3512. E-mail: carmenparisotto@gmail.com

${ }^{8}$ ORCID: http://orcid.org/0000-0001-7892-5773. E-mail: sfblima@gmail.com

\begin{abstract}
The malacofauna bycatch of sea-bob shrimp Xiphopenaeus kroyeri (Heller, 1862) trawl fisheries on the coast of Sergipe was studied for 5 years. The malacofauna bycatch considered was obtained in nine oceanographic sampling campaigns carried out between May 1999 and June 2003 in 18 stations distributed in six transects along depths of 10,20 and $30 \mathrm{~m}$. A total of 2,669 individuals of mollusk belonging to 54 species were captured on the 18 sea-bob shrimp trawl stations carried out along the coast of Sergipe. The considerable richness of mollusks was composed by 19 families and 31 species of gastropods, 12 families and 19 species of bivalves and 2 families and 4 species of cephalopods. The highest abundance were observed at stations 13 (373 individuals) and 16 (685 individuals) that represents the lowest depth $(10 \mathrm{~m})$ and the richness was higher at stations 15 and 12 (17 and 11 species, respectively) both located at the highest depth (30 m). Cephalopods had high frequency of occurrence being collected in all the stations and by far the most abundant group with a total of 2,488 individuals captured. On the other hand, gastropods (with 142 individuals found in 83.3\% of stations) and bivalves (about 1\% of the individuals collected) contribute with a much smaller percentage of individuals captured. Lolliguncula brevis (Blainville, 1823) was most representative cephalopod in number and frequency of occurrence. Arcidae, Conidae, Muricidae and Strombidae were the families with the higher number of species in the trawl-fishery. Among bivalves, Pitar arestus (Dall \& Simpson, 1901) and Spathochlamys benedicti (Verrill \& Bush [in Verrill], 1897) were the species with higher frequency of occurrence. Although the considerable sample effort and a number of mollusks captured as bycath, the richness estimators indicated that the species richness could increase with additional sampling effort in the study area. The present study expands the taxonomic alpha knowledge on the mollusk bycatch of sea-bob shrimp trawl fisheries on the northeastern coast of Brazil. However, it is of crucial importance to assess urgently the negative impacts of the sea-bob shrimp trawl fisheries on the benthic community of the entire coast of Brazil.
\end{abstract}

Key-Words. Megafauna; Mollusks; Gastropoda; Bivalvia; Cephalopoda.

\section{INTRODUCTION}

Shrimp trawl fisheries constitute an activity of considerable economic importance on the coast of Brazil (Paiva-Filho \& Schmiegelow, 1986; Mendonça \& Barbieri, 2000; Braga et al., 2001; Paiva et al., 2001; Branco, 2005; Santos et al., 2006; Santos \& Silva, 2008; Rodrigues et al., 2015; Maia et al., 2016). However, the low selectivity of the fishing gear (Silva et al., 2013; Branco et al., 2015; Maia et al., 2016) leads to the capture of many benthic and demersal metazoans that belong to the vulnerable megafauna (Graça-Lopes et al., 2002a; Branco \& Verani, 2006a). Therefore, trawl fisheries have an extremely negative impact on the marine ecosystem, especially in the benthic community (Branco \& Fracasso, 2004), due to the severe disruption of the ocean floor (Paiva et al., 
2001) and the capture of numerous organisms that are subsequently discarded due to their lack of commercial value, the majority of which are killed in the process (Pacule \& Baltazar, 1995; Braga et al., 2001; Graça-Lopes et al., 2002b; Lewison et al., 2004; Branco \& Verani, 2006b).

The bycatch of shrimp trawl fisheries has a considerable richness of invertebrates (Graça-Lopes et al., 2002a; Branco \& Fracasso, 2004; Branco \& Verani, 2006b), such as cnidarians, echinoderms, mollusks and other crustaceans (Braga et al., 2001; Paiva et al., 2001; Graça-Lopes et al., 2002a, b; Branco \& Fracasso, 2004; Branco \& Verani, 2006b; Belz et al., 2018).

Despite the environmental impact, these operations contribute to knowledge on metazoan richness in a given region through the study of the individuals captured. In Brazil, studies on the bycatch of coastal shrimp fisheries have been carried out mainly on fish fauna (Paiva-Filho \& Schmiegelow, 1986; Braga et al., 2001; Graça-Lopes et al., 2002a; Branco \& Verani, 2006a, b; Sedrez et al., 2013), whereas few studies have performed a refined qualitative and quantitative analysis of invertebrate groups in the bycatch (Graça-Lopes et al., 2002a; Branco \& Fracasso, 2004; Branco \& Verani, 2006b; Branco et al., 2015).

Mollusca is the most specious phylum of marine ecosystems (Bouchet et al., 2002; Bouchet, 2006), especially in tropical habitats (Bouchet et al., 2002, 2016), and undoubtedly contributes significant richness and biomass to the bycatch of trawl fisheries around the world (Alverson et al., 1996; Riestra et al., 2006; Branco et al., 2015).

Shrimp trawling is practiced throughout the Brazilian Exclusive Economic Zone (Santos et al., 2006). In northeastern Brazil, about 1,560 motorized and non-motorized vessels operate along 3,413 km of coastline, exclusively exploiting populations of the family Penaeidae (Santos et al., 2006). The fishing and commercial exploitation of the Atlantic seabob Xiphopenaeus kroyeri (Heller, 1862) on the coast of Sergipe (northeastern Brazil) is one of the most important economic activities in the region (Guimarães \& Landim, 2017). The participation of mollusk bycatch in such fisheries is usually high, surpassing many groups of invertebrates in terms of species richness. However, many of the mollusks caught are small and have no commercial value.

The present study represents the first effort to know the mollusk bycatch in shrimp trawl fisheries on the coast of the state of Sergipe and is an important step toward a better understanding of the diversity of the group on the continental shelf of the state. Besides that, this work aims to perform a qualitative and quantitative analysis of the mollusk bycatch in artisanal fishing operations targeting the Atlantic seabob on the coast of the state of Sergipe, northeastern Brazil.

\section{MATERIALS AND METHODS}

\section{Study area}

The coast of the state of Sergipe $\left(10^{\circ} 30^{\prime}-11^{\circ} 40^{\prime} \mathrm{S}\right.$, $37^{\circ} 25^{\prime}-36^{\circ} 10^{\prime} \mathrm{W}$ ) is $168 \mathrm{~km}$ long (Guimarães, 2010;
Lemos Júnior, 2011) and involves the continental shelf and the beginning of the continental slope (Guimarães \& Landim, 2017). It is a depositional environment with a smooth declivity, small width (between 12 to $35 \mathrm{~km}$ ) and variable depths (mean: $41 \mathrm{~m}$ ) in the limit between continental shelf and slope (Guimarães, 2010; Lemos Júnior et al., 2014; Guimarães \& Landim, 2017). The shelf is strongly influenced by the intense river inputs, especially the estuaries of the São Francisco to the north, Japaratuba, Sergipe and Vaza-Barris rivers and the PiauíFundo-Real river complex to the south (Guimarães, 2010; Lemos Júnior, 2011), which give rise to five underwater canyons (Guimarães, 2010; Lemos Júnior et al., 2014). This environment is dominated by fine terrigenous sediment, a sandy bottom in the coastal region and a gravel bottom in deeper regions (Guimarães, 2010; Guimarães \& Landim, 2017).

\section{Sampling design, identification and analysis}

The fauna considered in this study was obtained during oceanographic sampling in nine campaigns carried out between May 1999 and June 2003 (May, August and December 1999; March 2000; December 2001; June and December 2002; and June 2003). Eighteen stations between $10^{\circ} 36^{\prime}$ to $11^{\circ} 21^{\prime} \mathrm{S}$ and $36^{\circ} 32^{\prime}$ to $37^{\circ} 05^{\prime} \mathrm{W}$ were sampled (Table 1). These stations were distributed in six transects (a to f) along depths of 10, 20 and 30 m (Fig. 1). Double trawls were performed using fishing trawlers with net sizes and mesh openings equal to those used by the local shrimp fishing fleet (mesh opening: $35 \mathrm{~mm}$ in the sleeves, $30 \mathrm{~mm}$ in the body and $25 \mathrm{~mm}$ in the drawer).

The material collected was processed immediately after sampling and deposited in the zoological collection of the Laboratório de Bentos Costeiro da Universidade Federal de Sergipe (CZUFS). Mollusks were separated from other taxa and identified mainly based on Rios (2009), Tunnell Jr. et al. (2010) and Redfern (2013). The trophic groups considered here are based on Rueda et al. (2009).

We estimated the richness and abundance at each station. The frequency of occurrence (FO\%) of each taxa

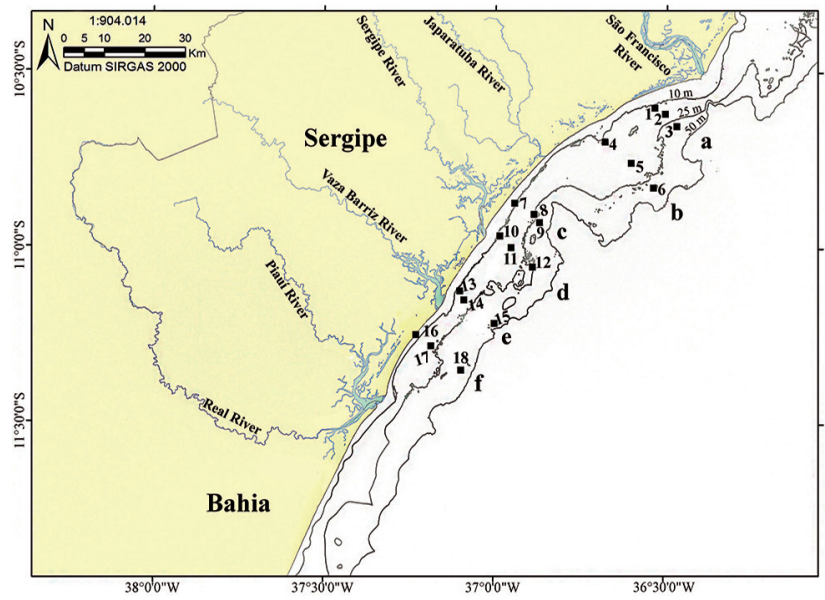

Figure 1. Map of study area showing sampling stations and transects on continental shelf off state of Sergipe. 
Table 1. Shrimp trawl sampled stations on the continental shelf of Sergipe, northeastern Brazil.

\begin{tabular}{|c|c|c|c|c|c|}
\hline Station & Coordinates & Depth & Abundance & Richness & Date \\
\hline 1 & $10^{\circ} 36^{\prime} 08^{\prime \prime} \mathrm{S}, 36^{\circ} 32^{\prime} 03^{\prime \prime} \mathrm{W}$ & $10 \mathrm{~m}$ & 145 & 02 & May, August, December 1999; March 2000; June, December 2001; June, December 2002; June 2003 \\
\hline 2 & $10^{\circ} 37^{\prime} 09^{\prime \prime} \mathrm{S}, 36^{\circ} 30^{\prime} 12^{\prime \prime} \mathrm{W}$ & $20 \mathrm{~m}$ & 98 & 05 & May, August, December 1999; March 2000; June, December 2001; June, December 2002; June 2003 \\
\hline 3 & $10^{\circ} 39^{\prime} 15^{\prime \prime} \mathrm{S}, 36^{\circ} 28^{\prime} 10^{\prime \prime} \mathrm{W}$ & $30 \mathrm{~m}$ & 94 & 03 & May, August, December 1999; March 2000; June, December 2001; June, December 2002; June 2003 \\
\hline 4 & $10^{\circ} 41^{\prime} 59^{\prime \prime} S, 36^{\circ} 40^{\prime} 43^{\prime \prime} \mathrm{W}$ & $10 \mathrm{~m}$ & 57 & 04 & May, August, December 1999; March 2000 \\
\hline 5 & $10^{\circ} 45^{\prime} 36^{\prime \prime} \mathrm{S}, 36^{\circ} 36^{\prime} 08^{\prime \prime} \mathrm{W}$ & $20 \mathrm{~m}$ & 37 & 04 & May, August, December 1999; March 2000 \\
\hline 6 & $10^{\circ} 49^{\prime} 47^{\prime \prime S}, 36^{\circ} 32^{\prime} 10^{\prime \prime} \mathrm{W}$ & $30 \mathrm{~m}$ & 07 & 06 & May, August, December 1999; March 2000 \\
\hline 7 & $10^{\circ} 52^{\prime} 33^{\prime \prime} \mathrm{S}, 36^{\circ} 56^{\prime} 32^{\prime \prime} \mathrm{W}$ & $10 \mathrm{~m}$ & 108 & 04 & May, August, December 1999; March 2000; June, December 2001; June, December 2002; June 2003 \\
\hline 8 & $10^{\circ} 54^{\prime} 26^{\prime \prime} \mathrm{S}, 36^{\circ} 53^{\prime} 09^{\prime \prime} \mathrm{W}$ & $20 \mathrm{~m}$ & 179 & 07 & May, August, December 1999; March 2000; June, December 2001; June, December 2002; June 2003 \\
\hline 9 & $10^{\circ} 55^{\prime} 51^{\prime \prime} \mathrm{S}, 36^{\circ} 52^{\prime} 10^{\prime \prime} \mathrm{W}$ & $30 \mathrm{~m}$ & 112 & 10 & May, August, December 1999; March 2000; June, December 2001; June, December 2002; June 2003 \\
\hline 10 & $10^{\circ} 58^{\prime} 09^{\prime \prime} \mathrm{S}, 36^{\circ} 59^{\prime} 07^{\prime \prime} \mathrm{W}$ & $10 \mathrm{~m}$ & 153 & 02 & May, August, December 1999; March 2000; June, December 2001; June, December 2002; June 2003 \\
\hline 11 & $11^{\circ} 00^{\prime} 08^{\prime \prime} S, 36^{\circ} 57^{\prime} 07^{\prime \prime} \mathrm{W}$ & $20 \mathrm{~m}$ & 53 & 06 & May, August, December 1999; March 2000; June, December 2001; June, December 2002; June 2003 \\
\hline 12 & $11^{\circ} 03^{\prime} 26^{\prime \prime S}, 36^{\circ} 53^{\prime} 21^{\prime \prime} \mathrm{W}$ & $30 \mathrm{~m}$ & 40 & 11 & May, August, December 1999; March 2000; June, December 2001; June, December 2002; June 2003 \\
\hline 13 & $11^{\circ} 07^{\prime} 36^{\prime \prime} \mathrm{S}, 37^{\circ} 06^{\prime} 06^{\prime \prime} \mathrm{W}$ & $10 \mathrm{~m}$ & 373 & 04 & May, August, December 1999; March 2000; June, December 2001; June, December 2002; June 2003 \\
\hline 14 & $11^{\circ} 09^{\prime} 08^{\prime \prime} \mathrm{S}, 37^{\circ} 05^{\prime} 23^{\prime \prime} \mathrm{W}$ & $20 \mathrm{~m}$ & 215 & 05 & May, August, December 1999; March 2000; June, December 2001; June, December 2002; June 2003 \\
\hline 15 & $11^{\circ} 13^{\prime} 07^{\prime \prime} \mathrm{S}, 37^{\circ} 00^{\prime} 00^{\prime \prime} \mathrm{W}$ & $30 \mathrm{~m}$ & 121 & 17 & May, August, December 1999; March 2000; June, December 2001; June, December 2002; June 2003 \\
\hline 16 & $11^{\circ} 15^{\prime} 06^{\prime \prime} \mathrm{S}, 37^{\circ} 13^{\prime} 47^{\prime \prime} \mathrm{W}$ & $10 \mathrm{~m}$ & 685 & 7 & May, August, December 1999; March 2000; June, December 2001; June, December 2002; June 2003 \\
\hline 17 & $11^{\circ} 17^{\prime} S, 37^{\circ} 11^{\prime} 07^{\prime} \mathrm{W}$ & $20 \mathrm{~m}$ & 157 & 05 & May, August, December 1999; March 2000; June, December 2001; June, December 2002; June 2003 \\
\hline 18 & $11^{\circ} 21^{\prime} 07^{\prime \prime} \mathrm{S}, 37^{\circ} 05^{\prime} 50^{\prime \prime} \mathrm{W}$ & $30 \mathrm{~m}$ & 26 & 05 & May, August, December 1999; March 2000; June, December 2001; June, December 2002; June 2003 \\
\hline
\end{tabular}

was determined by dividing the total number of stations that each taxa was found by the total number of stations with Mollusca and multiplying by 100 . Taxa identified on the genus level were considered for the determination of richness when only one species of the genus was found.

We compared total observed richness to that expected using the Chao 1, first-order J jackknife (Jack 1) estimators and Bootstrap randomized 500 times on EstimateS (Version 9.1.0) (Colwell, 2013).

Images were obtained using a digital camera (Canon DSLR EOS Rebel T5i) and/or a stereoscopic microscope (Leica M205C and Leica Application Suit v4.4). Specimens were preserved in $70 \%$ ethanol and re-deposited at the scientific zoological collection of the Universidade Federal de Sergipe, Sergipe, Brazil (CZUFS).

\section{RESULTS}

The present study provides important insights regarding the composition of the mollusk fauna on the continental shelf off the state of Sergipe, Brazil, for which few data have been published thus far. During the study period, a total of 2,669 individuals belonging to $54 \mathrm{~mol}$ lusk species were captured at 18 Atlantic seabob trawl stations along the coast of the state. This total was represented by 19 families and 31 species of gastropods (accounting for approximately $57.4 \%$ of the composition Fig. 2, Table 2), 12 families and 19 species of bivalves (approximately $35.2 \%$ of the composition - Fig. 3, Table 3) as well as two families and four species of cephalopods (approximately $7.4 \%$ of the composition - Fig. 4, Table 4). The following taxa were not identified on the species level due to the poor state of preservation of the shells and/ or the fact that they were juveniles: Aplysia sp., Siratus sp. and Strombus sp. (Gastropoda); Chama sp., Chlamys sp., Corbula sp., Ostrea sp. and Spondylus sp. (Bivalvia); Loligo sp. and Octopus sp. (Cephalopoda). Tables 2-4 show the Mollusca richness obtained in each of the stations and respective depth sampled in this study as bycatch of trawl fisheries targeting the Atlantic seabob shrimp X. kroyeri on the coast of Sergipe.

Among the fifty-four species of mollusks identified in this study, 39 (about $72.22 \%$ of the observed richness) are widely distributed in the western Atlantic (e.g., Arca zebra Swainson, 1833; Spathochlamys benedicti (Verrill \& Bush [in Verrill], 1897); Pitar arestus (Dall \& Simpson, 1901); Architectonica nobilis Röding, 1798; Cancellaria reticulata (Linnaeus, 1767); Conasprella centurio (Born, 1778); Phyllonotus oculatus (Reeve, 1845); Doryteuthis pleii (Blainville, 1823); Lolliguncula brevis (Blainville, 1823) and Callistoctopus macropus (Risso, 1826)), while only seven species (about $12.96 \%$ of the observed richness) are reported only for the coast of Brazil (e.g., Americoliva circinata (Marrat, 1871); Arcinella brasiliana (Nicol, 1953); Bullata largillieri (Kiener, 1841); Lobatus goliath (Schröter, 1805); Vasum cassiforme (Kiener, 1840); Voluta ebraea Linnaeus, 1758; and Siratus senegalensis (Gmelin, 1791)). The majority of mollusks were collected alive, but the identification of the species Architectonica nobilis, A. brasiliana, Bulla striata Bruguière, 1792, Columbella mercatoria (Linnaeus, 1758), Chama sp. and Siratus sp. were based only on the shells.

The families with the highest numbers of species in the trawl fisheries on the coast of Sergipe were Arcidae, Conidae and Muricidae (each with three species) and Strombidae (four species). These four groups accounted for $24 \%$ of the species sampled. Calyptraeidae, Columbellidae and Turbinidae are families of gastropods, most known species of which have a shell length measuring between 5 and $37 \mathrm{~mm}$. Due to this fact, we found only one to two species from each group retained in the net.

By far, cephalopods were the most abundant group, with a total of 2,488 individuals captured $(93.21 \%$ of the total sampled) and a high frequency of occurrence, sampled at all stations (Table 4). Lolliguncula brevis was the most representative in number, biomass and frequency 


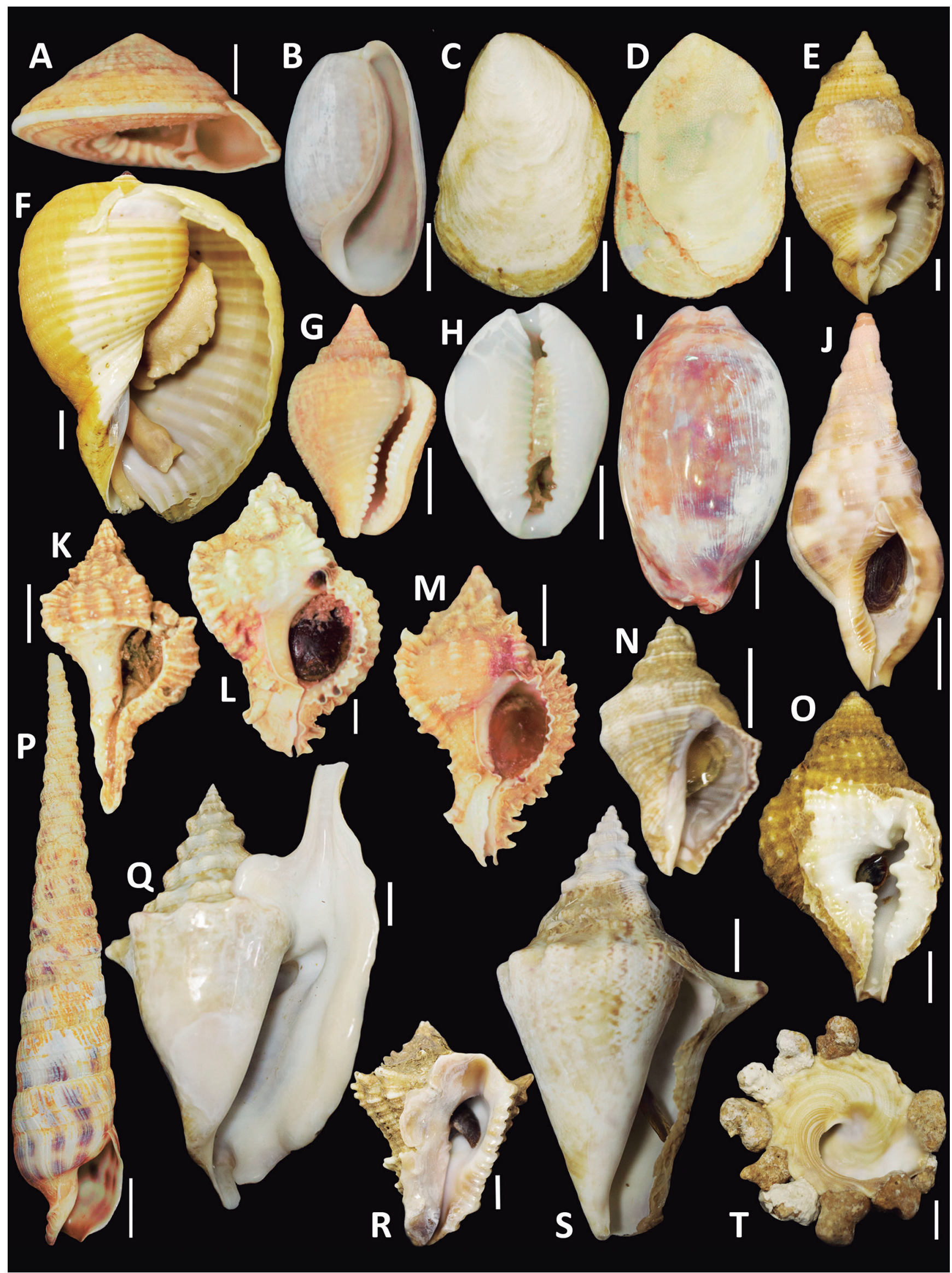

Figure 2. Gastropoda bycatch of trawl fisheries targeting Xiphopenaeus kroyeri on coast of Sergipe: (A) Architectonica nobilis, (B) Bulla striata, (C) Crepidula plana, (D) Crepidula protea, (E) Cancellaria reticulata, (F) Tonna galea, (G) Columbella mercatoria, (H) Erosaria acicularis, (I) Macrocypraea zebra, (J) Charonia variegate, (K) Siratus sp., (L) Phyllonotus oculatus, (M) Siratus senegalensis, (N) Stramonita brasiliensis, (0) Distorsio clathrata, (P) Terebra taurina, (Q) Lobatus gallus, (R) Vasum cassiforme, (S) Voluta ebraea, (T) Xenophora conchyliophora. Scale bars: A-E, G-H, K-0 = 5 mm; F, I-J, P-Q, S-T $=10 \mathrm{~mm}$. 
Table 2. Gastropoda bycatch of trawl fisheries targeting the seabob shrimp Xiphopenaeus kroyeri on coast of Sergipe. The asterisk $\left(^{*}\right)$ means that the information about the station was lost for the taxa.

\begin{tabular}{|c|c|c|c|c|c|c|c|c|c|c|c|c|c|c|c|c|c|c|c|c|}
\hline \multirow{2}{*}{ Taxa } & \multicolumn{18}{|c|}{ Station } & \multirow{2}{*}{ Total } & \multirow{2}{*}{ Voucher CZUFS } \\
\hline & 1 & 2 & 3 & 4 & 5 & 6 & 7 & 8 & 9 & 10 & 11 & 12 & 13 & 14 & 15 & 16 & 17 & 18 & & \\
\hline \multicolumn{21}{|l|}{ Gastropoda } \\
\hline \multicolumn{21}{|l|}{ Aplysiidae } \\
\hline Aplysia sp. & & & & & & & & & & & & 02 & & & & & & & 02 & \\
\hline \multicolumn{21}{|l|}{ Architectonicidae } \\
\hline Architectonica nobilis & & & & & & & & & & & & & & & & & 01 & & 01 & 000374 \\
\hline \multicolumn{21}{|l|}{ Bullidae } \\
\hline Bulla striata & & & & & & & & & & & & & & & & & & & $01^{*}$ & 000419 \\
\hline \multicolumn{21}{|l|}{ Calyptraeidae } \\
\hline Crepidula plana Say, 1822 & & & & & & & & & & & & 01 & & & & & & & 01 & 000394 \\
\hline Crepidula protea (d'Orbigny, 1841) & & 02 & & & & & & & & & & & & & & & & & 02 & 000375 \\
\hline \multicolumn{21}{|l|}{ Cancellariidae } \\
\hline Cancellaria reticulata & & & & & & & & & & & & & & & & & & & $01^{*}$ & 000418 \\
\hline Columbellidae & & & & & & & & & & & & & & & & & & & & \\
\hline Anachis lyrata (G.B. Sowerby I, 1832) & & & & & & & & & & & & & & & & 01 & & & 01 & 000384 \\
\hline Columbella mercatoria & & & & & 01 & & & & & & & & & & & 01 & & & 02 & 000393 \\
\hline Conidae & & & & & & & & & & & & & & & & & & & & \\
\hline Conasprella centurio & & & & & & & & & & & & & & & 06 & & & & 06 & 000362 \\
\hline Conasprellajaspidea & & & & & & & & & & & & & & & & & & 01 & 01 & 000361 \\
\hline Conus ziczac Megerle von Mühlfeld, 1816 & & & & & & 01 & & & & & & & & & & & & & 01 & 000393 \\
\hline Cypraeidae & & & & & & & & & & & & & & & & & & & & \\
\hline Macrocypraea zebra & & & & & & & & & & & & 01 & & & & & & & 01 & 000376 \\
\hline Naria acicularis (Gmelin, 1791) & & & & & & 01 & & & & & & & & & & & & & 01 & 000383 \\
\hline Marginellidae & & & & & & & & & & & & & & & & & & & & \\
\hline Bullata largillieri & & & & & & & & & & & & & & & 01 & & & & 01 & 000369 \\
\hline Cryptospira strigata (Dillwyn, 1817) & & & & & & & & & & & & 01 & & & & & & & 01 & 000386 \\
\hline Muricidae & & & & & & & & & & & & & & & & & & & & \\
\hline Phyllonotus oculatus & & & & & & & & & & & & & & & 01 & & & & 01 & 000363 \\
\hline Siratus senegalensis & & & & & & & & & & & & 01 & & & & & & & 01 & 000388 \\
\hline Siratus sp. & & & & & & & & & 01 & & & & & & & & & & 01 & \\
\hline Stramonita brasiliensis & & & & & & & & & & & 01 & & 01 & & & & & & 02 & 000373 \\
\hline Olividae & & & & & & & & & & & & & & & & & & & & \\
\hline Americoliva circinata & & & & & & & & & & & & & & & 02 & & & & 02 & 000366 \\
\hline Personidae & & & & & & & & & & & & & & & & & & & & \\
\hline Distorsio clathrata (Lamarck, 1816) & 02 & 04 & & & & & 05 & 04 & 06 & & 02 & & & 05 & 04 & & 01 & 02 & 35 & 000367 \\
\hline Ranellidae & & & & & & & & & & & & & & & & & & & & \\
\hline Charonia variegata & & & & & & & & & & & & & & & 01 & & & & 01 & 000377 \\
\hline Strombidae & & & & & & & & & & & & & & & & & & & & \\
\hline Lobatus costatus & & & & & & & & & & & & & & & 03 & 02 & & & 05 & 000378 \\
\hline Lobatus gallus (Linnaeus, 1758) & & & & & & 01 & & & & & & & & & & & & & 01 & 000387 \\
\hline Lobatus goliath & & & & & & 01 & & & & & & & & & & & & & 01 & 000381 \\
\hline Strombus pugilis & & & & & & & & & 01 & & & & & & & & & & 01 & 000382 \\
\hline Strombus sp. & & & & & & & 01 & & & & & & & & & & & & 01 & \\
\hline Terebridae & & & & & & & & & & & & & & & & & & & & \\
\hline Terebra taurina (Lightfoot, 1786) & & & & & & & & & & & & 01 & & & & & & & 01 & 000395 \\
\hline Tonnidae & & & & & & & & & & & & & & & & & & & & \\
\hline Tonna galea & & & & & & & & & & & & & & 01 & & 01 & 03 & & 05 & 000359 \\
\hline Turbinellidae & & & & & & & & & & & & & & & & & & & & \\
\hline Vasum cassiforme & & & & & 01 & & & & & & & 08 & & & 08 & & & & 17 & 000365 \\
\hline Turbinidae & & & & & & & & & & & & & & & & & & & & \\
\hline Lithopoma phoebium (Röding, 1798) & & & & & 01 & & & & & & & & & & & & & & 01 & 000370 \\
\hline Volutidae & & & & & & & & & & & & & & & & & & & & \\
\hline Voluta ebraea & & & & & & & & & & & & & & & & & & 01 & 01 & 000392 \\
\hline Xenophoridae & & & & & & & & & & & & & & & & & & & & \\
\hline Xenophora conchyliophora & & & & & & & & & & & 01 & 16 & & & 12 & & & 14 & 43 & 000368 \\
\hline Total & 02 & 06 & 00 & 00 & 03 & 04 & 06 & 04 & 08 & 00 & 04 & 31 & 01 & 06 & 38 & 05 & 05 & 18 & 143 & \\
\hline
\end{tabular}


of occurrence and was, by far, the most abundant lolliginid (2,381 individuals collected at $89 \%$ of stations) (Fig. 4B). Loligo sp. was the second most abundant lolliginid. Doryteuthis pleii and L. brevis co-occurred at nine stations, whereas Loligo sp. and L. brevis were sampled together at 10 stations, and D. pleii and Lolligo sp. Co-occurred at six stations (Table 4). Among Octopodidae, Octopus sp. was sampled at only $16.66 \%$ of stations, whereas C. macropus (Fig. 4A) was caught at only one station (Table 4).
Gastropoda was the second most abundant group, with a total of 142 individuals caught at $83.3 \%$ of the stations (Table 2). Xenophora conchyliophora (Born, 1780) (Fig. 2T) predominated in abundance (43 individuals), although this species has been collected at four stations. Distorsio clathrata (Lamarck, 1816) (Fig. 2O) was the second most abundant species (35 individuals) collected at $55.55 \%$ of the stations, which was followed in abundance by $V$. cassiforme (Fig. 2R) with 17 individuals collected at three stations (16.66\% - Table 2$)$.

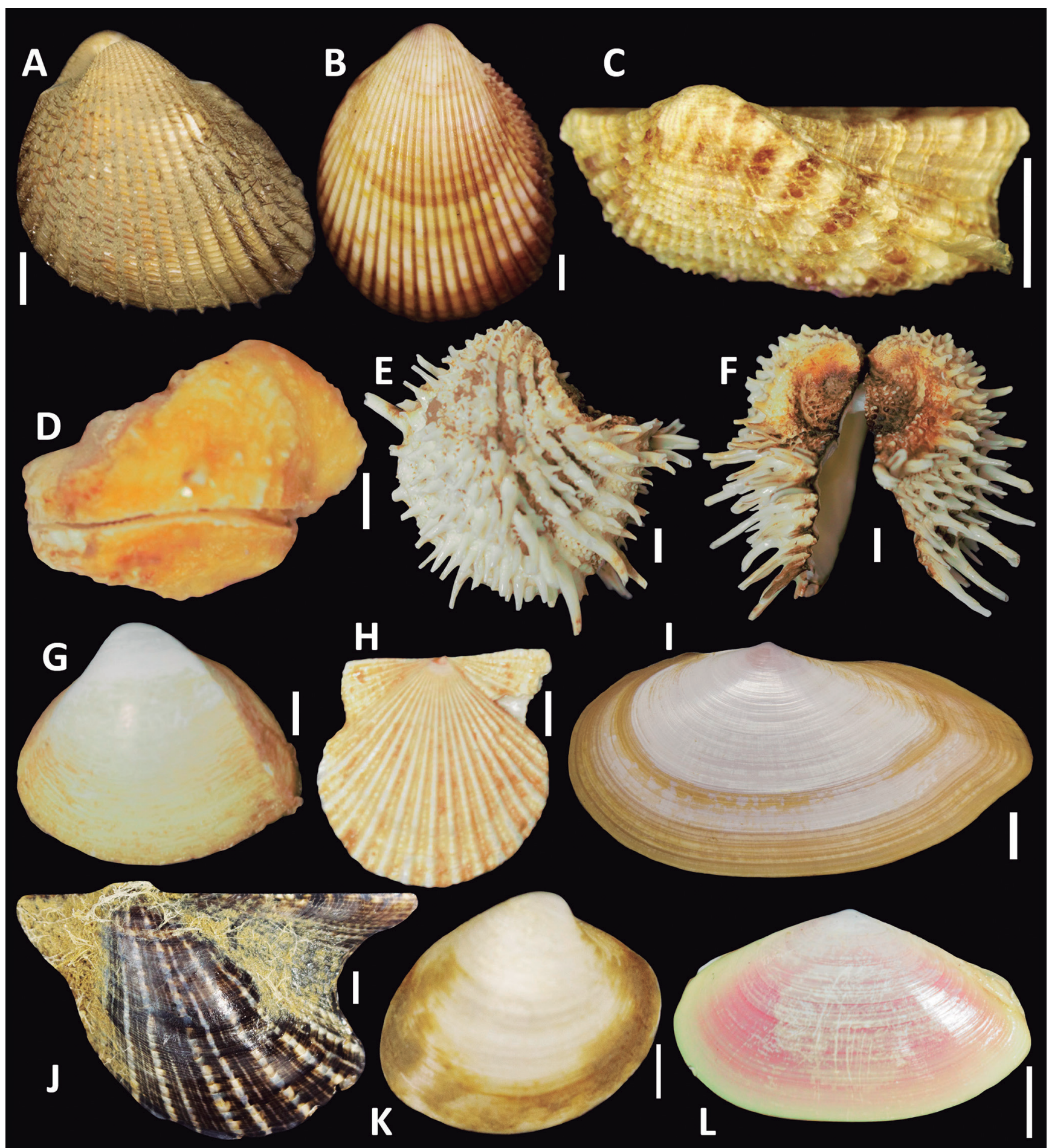

Figure 3. Bivalvia bycatch of trawl fisheries targeting Xiphopenaeus kroyeri on coast of Sergipe: (A) Anadara chemnitzii, (B) Acrosterigma magnum, (C) Arca zebra, (D) Chama sp., (E-F) Arcinella brasiliana, (G) Mulinia cleryana, (H) Spathochlamys benedicti, (I) Psammotella cruenta, (J) Pteria colymbus, (K) Pitar aresta, (L) Eurytellina punicea. Scale bars: A-B, E-F, I-J, L $=5 \mathrm{~mm} ; \mathrm{C}-\mathrm{D}, \mathrm{G}-\mathrm{H}, \mathrm{K}=2 \mathrm{~mm}$. 
Table 3. Bivalvia bycatch of trawl fisheries targeting the seabob shrimp Xiphopenaeus kroyeri on coast of Sergipe. The asterisk $\left(^{*}\right)$ means that the information about the station was lost for the taxa.

\begin{tabular}{|c|c|c|c|c|c|c|c|c|c|c|c|c|c|c|c|c|c|c|c|c|}
\hline \multirow{2}{*}{ Taxa } & \multicolumn{18}{|c|}{ Station } & \multirow{2}{*}{ Total } & \multirow{2}{*}{ Voucher CZUFS } \\
\hline & 1 & 2 & 3 & 4 & 5 & 6 & 7 & 8 & 9 & 10 & 11 & 12 & 13 & 14 & 15 & 16 & 17 & 18 & & \\
\hline \multicolumn{21}{|l|}{ Bivalvia } \\
\hline \multicolumn{21}{|l|}{ Arcidae } \\
\hline Anadara chemnitzii (Philippi, 1851) & & & & & & & & & 01 & & & & & & & & & & 01 & 000340 \\
\hline Anadara nobilis & & & & & & & & & & & & & & & 01 & & & & 01 & 000339 \\
\hline Arcazebra & & & & & & & & & & & & & & & 01 & & & & 01 & 000337 \\
\hline \multicolumn{21}{|l|}{ Cardiidae } \\
\hline Acrosterigma magnum (Linnaeus, 1758) & & & & & & 02 & & & & & & & & & & & & & 02 & 000336 \\
\hline Dallocardia muricata & & & & & & & & & & & & & & & & & & 01 & 01 & 000344 \\
\hline \multicolumn{21}{|l|}{ Chamidae } \\
\hline Arcinella brasiliana & & & & & & & & & 01 & & & & & & & & & & 01 & 000357 \\
\hline Chama sp. & & & & & & & & & & & & 01 & & & 02 & & & & 03 & \\
\hline \multicolumn{21}{|l|}{ Corbulidae } \\
\hline Corbula sp. & & & & & & & & 02 & & & & & & & & & & & 02 & \\
\hline \multicolumn{21}{|l|}{ Mactridae } \\
\hline Mactrellona alata (Spengler, 1802) & & & & 01 & & & & & & & & & & & & & & & 01 & 000358 \\
\hline Mulinia cleryana (d'Orbigny, 1846) & & & & & & & & & & & & & & 01 & & & & & 01 & 000343 \\
\hline \multicolumn{21}{|l|}{ Ostreidae } \\
\hline Ostrea sp. & & & & & & & & & & & & & & & 01 & & & & 01 & \\
\hline Pectinidae & & & & & & & & & & & & & & & 01 & & & & 01 & \\
\hline Chlamys sp. & & & & & & & & & & & & & & & 01 & & & & 01 & \\
\hline Spathochlamys benedicti & & & & & & & & & 01 & & & 01 & & & 01 & & & & 03 & 000352 \\
\hline \multicolumn{21}{|l|}{ Psammobiidae } \\
\hline Psammotella cruenta (Lightfoot, 1786) & & & & & & & 01 & & & & & & & & & & & & 01 & 000345 \\
\hline Pteriidae & & & & & & & & 01 & & & & & & & & & & & 01 & \\
\hline Pteria colymbus (Röding, 1798) & & & & & & & & & & & & & & & & & & & $01^{*}$ & 000355 \\
\hline \multicolumn{21}{|l|}{ Spondylidae } \\
\hline Spondylus sp. & & & & & & & & & 01 & & & & & & & & & & 01 & \\
\hline \multicolumn{21}{|l|}{ Tellinidae } \\
\hline Eurytellina punicea (Born, 1778) & & & & & & & & & & & & & 01 & & & & & & 01 & 000356 \\
\hline \multicolumn{21}{|l|}{ Veneridae } \\
\hline Cyclinella tenuis (Récluz, 1852) & & & & & & & & 02 & & & & & & & & & & & 02 & 000346 \\
\hline Pitar arestus & & & 01 & & & & & 02 & 01 & & & & & & & & & & 04 & 000341 \\
\hline Total & 00 & 00 & 01 & 01 & 00 & 02 & 01 & 07 & 05 & 00 & 00 & 02 & 01 & 01 & 08 & 00 & 00 & 01 & 31 & \\
\hline
\end{tabular}

Bivalves composed approximately $1 \%$ of the individuals caught in the trawl fisheries (Fig. 3), with a total of 31 individuals sampled at $61.11 \%$ of the stations (Table 3 ). Pitar arestus (Fig. 3K) and S. benedicti (Fig. 3H) had the highest frequency of occurrence (16.7\%) in this group, although only four and three individuals were caught (Table 3), respectively.

Based on Rueda et al. (2009), the species of Mollusca studied here belong to five trophic groups: herbivores (macroalgae $-\mathrm{N}=10)$, filter feeders $(\mathrm{N}=21)$, carnivores $(\mathrm{N}=24)$, carrion feeders and scavengers $(\mathrm{N}=2)$. The xenophorid, aplysiid, turbinid, all strombids and the columbellid Columbella mercatoria represent some of the herbivorous gastropods identified. Only filter feeders were found among the bivalves, with gastropods of the family Calyptraeidae also included in this trophic group. All cephalopods and the majority of gastropods were carnivorous mollusks. Some of the gastropod carrion feeders and scavengers were ranellids and olivids.

Abundance was higher with the shallowest depth $(10 \mathrm{~m})$, whereas richness was greater at stations with the lowest depth (30 m). Stations 16 and 13 had the high- est abundance (685 and 373 individuals, respectively), whereas stations 15 and 12 had the greatest richness (17 and 11 species, respectively). Stations with a depth of $10 \mathrm{~m}$ were represented by 1,521 individuals and 12 species; stations with a depth of $20 \mathrm{~m}$ had a total of 739 individuals and 16 species and stations with a depth of $30 \mathrm{~m}$ had a total of 400 individuals and 38 species.

Mean observed richness was 30.76 ( \pm 13.77 ), corresponding to $51.08,60.29$ and $78.87 \%$ of mean richness estimated by Chao 1 (Sest $=60.22 \pm 28.17$ ), Jack 1 $($ Sest $=51.02 \pm 24.54)$ and Bootstrap (Sest $=38.99 \pm 17.96)$, respectively. The species accumulation curves are shown in Fig. 5.

\section{DISCUSSION}

The lack of proper monitoring of the fishing fleet and the lack of data on the invertebrate bycatch of trawl fisheries along the coast of Brazil is extremely troublesome due to the impact of this highly predatory activity on communities of organisms, leading to a loss of 
biodiversity (Branco \& Fracasso, 2004; Branco \& Verani, 2006a). Despite the immense fishing pressure on shrimp stocks on the coast of Brazil, especially in the northeastern region of the country, few studies have addressed the benthic community captured as bycatch during such activities. For instance, only information about the crustaceans (Santos et al., 2016) has been published on the benthic invertebrate bycatch on the coast of the state of Sergipe, where shrimp trawling is an activity of considerable economic importance in the Exclusive Economic Zone (Guimarães \& Landim, 2017). In our research, studies about the invertebrate bycatch in the Brazilian Exclusive Economic Zone are limited mainly to cnidarians, crustaceans, echinoderms and mollusks and generally are representative of southwest and south of Brazil (Pires-Vanin, 1992; Paiva et al., 2001; Graça-Lopes et al., 2002a, b; Branco \& Fracasso, 2004; Branco \& Verani, 2006a, b; De Léo \& Pires-Vanin, 2006; Branco et al., 2015; Belz et al., 2018). Furthermore, some of those studies identified the invertebrates caught only on supra-specific level (Graça-Lopes et al., 2002b; Branco \& Fracasso, 2004; Branco \& Verani, 2006a, b).

Mollusks constitute one of the most diverse groups of the benthic megafauna sampled during trawling activities (Pires-Vanin, 1992; De Léo \& Pires-Vanin, 2006) and are among the main invertebrates accidentally caught in fisheries in Brazil (Pires-Vanin, 1992; Paiva et al., 2001; Branco \& Verani, 2006a, b; Graça-Lopes et al., 2002a; Branco et al., 2015) as well as other coastal marine ecoregions around the world (Riestra et al., 2006; Prabhu et al., 2013; Öndes et al., 2018), in some cases, superseded in richness only by crustaceans (Graça-Lopes et al.,

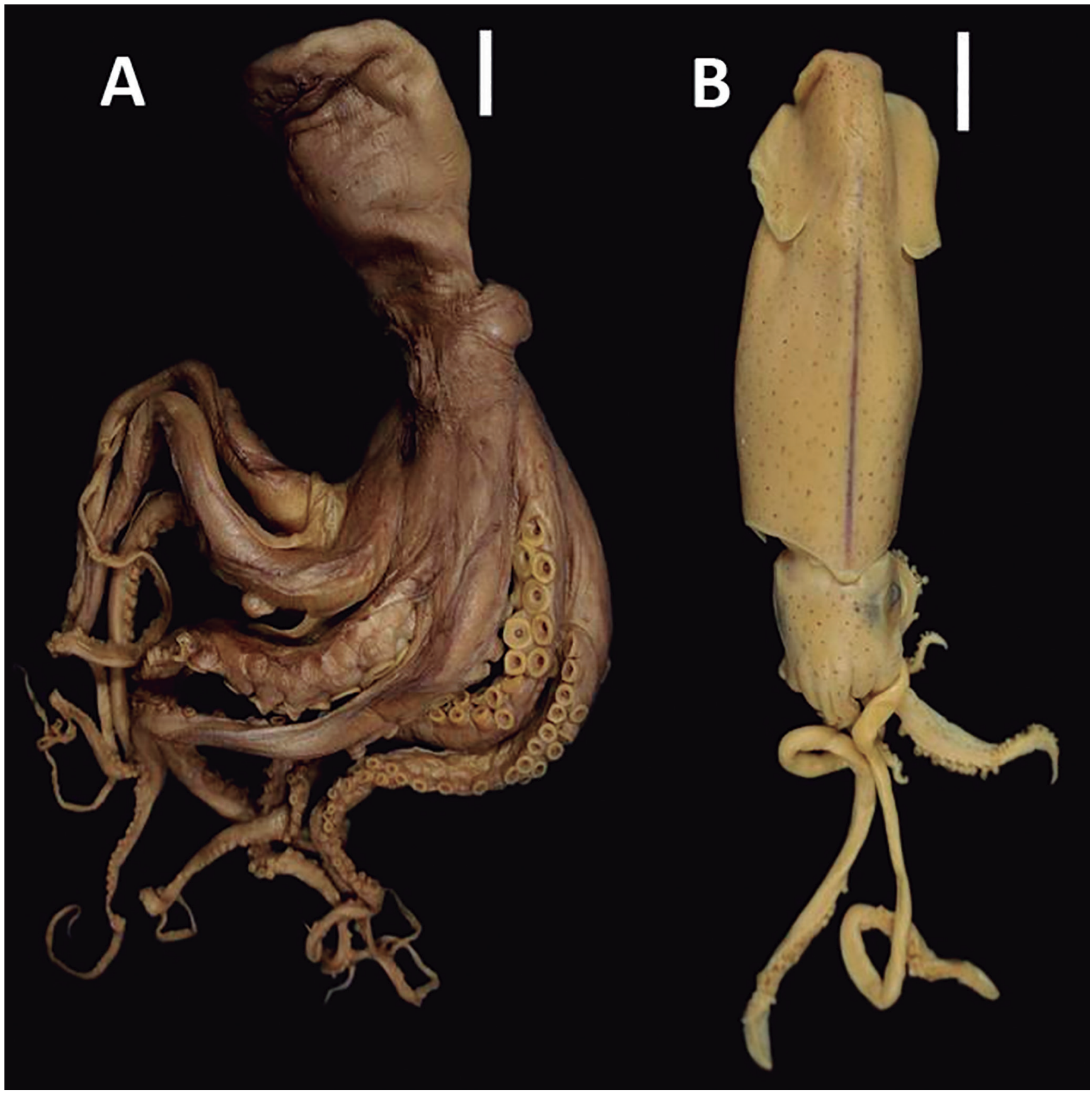

Figure 4. Cephalopoda bycatch of trawl fisheries targeting Xiphopenaeus kroyeri on coast of Sergipe: (A) Callistoctopus macropus, (B) Lolliguncula brevis. Scale bars: $1 \mathrm{~cm}$. 
Table 4. Cephalopoda bycatch of trawl fisheries targeting the seabob shrimp Xiphopenaeus kroyeri on coast of Sergipe.

\begin{tabular}{|c|c|c|c|c|c|c|c|c|c|c|c|c|c|c|c|c|c|c|c|c|}
\hline \multirow{2}{*}{ Taxon } & \multicolumn{18}{|c|}{ Station } & \multirow{2}{*}{ Total } & \multirow{2}{*}{$\begin{array}{l}\text { Voucher } \\
\text { UFS_MOL }\end{array}$} \\
\hline & 1 & 2 & 3 & 4 & 5 & 6 & 7 & 8 & 9 & 10 & 11 & 12 & 13 & 14 & 15 & 16 & 17 & 18 & & \\
\hline \multicolumn{21}{|l|}{ Cephalopoda } \\
\hline \multicolumn{21}{|l|}{ Loliginidae } \\
\hline Doryteuthis pleii & & 01 & & 01 & & & & 02 & 13 & 01 & 10 & & 02 & 07 & & 02 & & & 39 & 000397 \\
\hline Lolliguncula brevis & 143 & 86 & 86 & 40 & 34 & & 99 & 156 & 84 & 152 & 37 & 05 & 369 & 201 & 71 & 671 & 147 & & 2381 & 000396 \\
\hline Loligo sp. & & 05 & 07 & 15 & & & 01 & 10 & 02 & & 01 & & & & 04 & 07 & 05 & & 57 & \\
\hline \multicolumn{21}{|l|}{ Octopodidae } \\
\hline Callistoctopus macropus & & & & & & 01 & & & & & & & & & & & & & 01 & 000401 \\
\hline Octopus sp. & & & & & & & & & & & 01 & 02 & & & & & & 07 & 10 & \\
\hline Total & 143 & 92 & 93 & 56 & 34 & 01 & 100 & 168 & 99 & 153 & 49 & 07 & 371 & 208 & 75 & 680 & 152 & 07 & 2488 & \\
\hline
\end{tabular}



Figure 5. Mollusca from continental shelf of Sergipe sampled with double trawls in four campaigns at 18 stations: observed richness (Sobs); mean estimated richness by Chao 1 and first order Jackknife (Jack 1) estimators and Bootstrap, randomized 500 times.

2002a, b; Branco \& Verani, 2006b; De Léo \& Pires-Vanin, 2006). However, data on Mollusca bycatch are scarce in Brazil (Belz et al., 2018) and even non-existent in view of the numerous fishing activities developed on the Brazilian continental shelf, especially on the coast of the state of Sergipe, where studies about the group are limited to a few taxonomic and ecological approaches (Lima \& Couto, 2001; Castro et al., 2005; Almeida et al., 2014; Lima et al., 2016).

The malacofauna composition identified as bycatch in the present study on the coast of the state of Sergipe and that found by Branco et al. (2015) for the coast of the state of Santa Catarina reveal considerable richness, represented mainly by gastropods. Mollusks common to both studies are members of the families Aplysiidae (e.g., Aplysia), Arcidae (e.g., Anadara), Cardiidae (e.g., Dallocardia muricata (Linnaeus, 1758)), Loliginidae (e.g., D. pleii and L. brevis), Muricidae (e.g., S. senegalensis and S. brasiliensis), Octopodidae (e.g., Octopus), Strombidae (e.g., Strombus pugilis Linnaeus, 1758), Tonnidae (e.g., Tonna galea (Linnaeus, 1758)) and Veneridae (e.g., P. arestus) (Branco et al., 2015). In contrast, a smaller percentage of mollusk species analyzed in this study were also reported for other areas on the coast of Brazil in studies involving trawl fisheries (Pires-Vanin, 1992; De Léo \& PiresVanin, 2006; Graça-Lopes et al., 2002a). Differences in composition in the different sampling areas on the coast of Brazil may be explained by environmental dynamics and characteristics, i.e., the continental shelf off Sergipe is a unique sedimentary mosaic influenced by river inputs dominated by fine sediments of terrigenous origin as well as sand and gravel (Guimarães, 2010; Guimarães \& Landim, 2017), spatial and temporal distribution, and the area of distribution of the species, i.e., Olivancillaria urceus (Röding, 1798) and/or Zidona dufresnei (Donovan, 1823) identified in studies published by Pires-Vanin (1992), Branco \& Verani (2006b), De Léo \& Pires-Vanin (2006), Graça-Lopes et al. (2002a, b) and Branco et al. (2015) do not occur in northeastern Brazil (Rios, 2009).

In the present investigation, considerable richness of mollusk bycatch was found in trawl fisheries on the coast of Sergipe, especially when compared to previous studies. Belz et al. (2018) performed sampling for more than a year on the coast the state of Paraná (Pontal do Paraná) and recorded no more than 10 species in trawl fisheries targeting X. kroyeri. Branco et al. (2015) sampled 22 species of Mollusca on the coast of the state of Santa Catarina. Graça-Lopes et al. (2002a) identified 25 mollusks collected on the coast of the state of São Paulo. Costa \& Di Beneditto (2009) found only eight species on the coast of the state of Rio de Janeiro.

Most of the benthic mollusks studied here have strictly coastal habits, commonly sampled in shallow areas (less than 100 meters depth) on the Brazilian continental shelf and other ecoregions of the western Atlantic (Diaz \& Puyana, 1994; Rios, 2009; Tunnell Jr. et al., 2010; Redfern, 2013). Architectonica nobilis, Charonia variegata (Lamarck, 1816), C. centurio, D. clathrata, T. galea and $X$. conchyliophora are among the few species studied here that can be found in deeper areas (below $105 \mathrm{~m}$ depth) in the Western Atlantic (Diaz \& Puyana, 1994; Rios, 2009; Tunnell Jr. et al., 2010).

The lolliginid, which was the most abundant taxon in the present study, seems to have similarities in terms of bathymetric and environmental requirements with the seabob shrimp $X$. kroyeri. Lolliguncula brevis occurs abundantly in shallow waters on the Brazilian coast and represented a large percentage of the bycatch of seabob shrimp fisheries in previous studies (Lopes, 1996, Branco \& Verani, 2006b).

The gastropods with higher abundance $(D$. clathrata, $V$. cassiforme and $X$. conchyliophora) were found mainly at depths of 20 and $30 \mathrm{~m}$, which are on the continental shelf 
off Sergipe. These locations are under less influence from the five estuarine regions and therefore receive a lower quantity of fine sediments. According to Diaz \& Puyana (1994), Rios (2009) and Tunnell Jr. et al. (2010), D. clathrata can be collected on sandy substrates at depths between 20 and $300 \mathrm{~m}$ and $V$. cassiforme can be found at depths reaching $60 \mathrm{~m}$ (Rios, 2009). Xenophora conchyliophora is also reported on sandy substrates in shallow waters at depths between 2 and 85 m (Diaz \& Puyana, 1994; Rios, 2009). However, Tunnell Jr. et al. (2010) reported this species at depths reaching $635 \mathrm{~m}$ depths on the coast of the state of Texas, USA.

Gastropods are among the main components of benthic communities and occupy a number of ecological niches (Beesley et al., 1998; Tunnell Jr. et al., 2010). Although not abundant in the present study, the group undoubtedly has considerable ecological importance, especially in marine food chains, where they serve as filter feeders [e.g., calyptraeids], herbivores [e.g., C. mercatoria, L. costatus (Gmelin, 1791), Macrocypraea zebra (Linnaeus, 1758)], carnivores [e.g., C. reticulata, C. centurio, P. oculatus], carrion feeders and scavengers [e.g., A. circinata, C. variegata] (Tunnell Jr. et al., 2010). Gastropods also compete for food with other invertebrates, such as crustaceans and appear in the diet of other metazoans. The large number of carnivorous (including cephalopods), detritivores, carrion-feeding and scavenger marine gastropods found in this study strongly contrasts the small percentage of herbivorous species collected in the trawls. The functional groups recognized here based on trophic strategies are qualitatively similar those found by Branco et al. (2015) on the coast of the state Santa Catarina.

The richness of bivalves caught on the coast of Sergipe corresponds to about one third of the total composition of Mollusca. Considerable variation was found between the number of families and species of bivalves captured as bycatch in the present study and findings described for other Brazilian coastal zones. The richness of bivalves found here (12 families, 14 species and five other supra-specific taxa) is higher in comparison to the eight families and 10 species found by Graça-Lopes et al. (2002a) and five families and six species found by Branco et al. (2015) in Atlantic seabob trawl fisheries in the states of São Paulo and Santa Catarina, respectively. The Bivalvia species identified here and also found on the studies mentioned above were: Arcidae (Anadara notabilis (Röding, 1798)), Cardiidae (D. muricata) and Veneridae (P. arestus), respectively.

Each one of the species of bivalves corresponded to a small number of individuals and occurred at only one of the 18 stations, except Chama sp., S. benedicti and P. arestus, which were recorded at three (the first two species) and four (the last species) stations at depths of 20 to $30 \mathrm{~m}$. The small number of bivalves sampled here and in the other studies mentioned could be due to the selectivity of the sampling method (trawls) as well as stations positioned at specific depths.

The mollusks caught on the coast of Sergipe do not have economic importance due the small size, small number of individuals captured or lack of commercial demand. Organisms caught during fishing activities that are not exploited economically, denominated 'trash, waste or discard', are thrown back into the sea, mainly dead (Graça-Lopes, 1996; Branco, 1999). This is one of the major economic and environmental problems in the maritime fishery sector and poses a threat to marine megafauna across the oceans of the world (Komoroske \& Lewison, 2015).

The ecological implications of the frequency of occurrence found for the different groups of epibenthic and nektonic mollusks caught on the continental shelf off Sergipe remain little understood. Thus, the identification of mollusk bycatch in trawl fisheries is an important step toward evaluating the ecological importance of the organisms that are being captured and, consequently, the impact of this fishing activity along the coast of Brazil.

Among the mollusks studied, only $C$. centurio and C. jaspidea (Gmelin, 1791) are on the IUCN Red List of Threatened Species (2018), listed under the status "least concern". The other taxa identified here and analyzed in a few studies have not yet been assessed for the IUCN Red List. However, this does not mean that they are free of danger, as many species of mollusks (e.g., D. pleii, L. brevis and $Z$. dufresnei) are under intense indirect fishing pressure, accounting for tons of bycatch in trawl fisheries on the coast of Brazil (Pires-Vanin, 1992; Branco \& Verani, 2006b; De Léo \& Pires-Vanin, 2006; Graça-Lopes et al., 2002a, b; Branco et al., 2015).

Sampling efforts, seasonal dynamics, environmental characteristics and lifestyles exert a strong influence on the capture of mollusks on the coast of Sergipe. Moreover, the richness found in the present study was more than $50 \%$ of the richness estimated using the Chao 1, Jack 1 and Bootstrap methods, demonstrating that fishery trawls have low selectivity, making this a high impact sampling method.

The present study expands taxonomic alpha knowledge on the Mollusca bycatch of trawl fisheries targeting the Atlantic seabob $X$. kroyeri on the northeastern coast of Brazil. Despite this positive aspect, the biological and ecological disturbances caused by trawl fisheries and the direct effects on the community of mollusks and other benthic invertebrate groups need to be urgently studied on the Brazilian coast as well as other marine ecoregions worldwide.

\section{ACKNOWLEDGMENTS}

The authors are grateful to PETROBRAS S.A. (Brazilian Petroleum Co.) for making the collection and study of material possible; the team of the "Laboratório de Bentos Costeiro of the Universidade Federal de Sergipe (UFS)" for processing the material and making the data available for study; the Brazilian fostering agency "Coordenação de Aperfeiçoamento de Pessoal de Nível Superior" (CAPES) for the scholarship granted to M. Sc. Luana M.C. Mendonça; to Dr. Luiz R.L. Simone (MZSP) and the anonymous reviewers for their contribution to the revision and correction of the manuscript. 


\section{REFERENCES}

Almeida, D.D.; Ribeiro, R.0.; Araújo, E.D.; Ferreira, M.H.A. \& Lopes, A.C.M. 2014. Identificação molecular de ostras Crassostrea spp. (Mollusca: Bivalvia) dos dois maiores estuários do estado de Sergipe por PCR/RFLP. Interfaces Científicas. Saúde e Ambiente, 2: 31-36.

Alverson, D.L.; Freeberg, M.H.; Murawski, S.A. \& Pope, J.G. 1996. A global assessment of fisheries bycatch and discards. FAO Fisheries Technical Paper, 339: 1-233.

Beesley, P.L.; Ross, G.J.B. \& Wells, A. 1998. Mollusca: The Southern Synthesis. Melbourne, CSIRO Publishing. 2v.

Belz, C.E.;Ziliotto, R.A.; Gernet, M.V.; Birckolz, C.J. \& Lagreze-Squella, F.J. 2018. Gastropoda and Bivalvia as bycatch of the Atlantic seabob, Xiphopenaeus kroyeri, trawl fisheries in Pontal do Paraná, southern Brazil. Strombus, 24: $5-12$.

Bouchet, P. 2006. The magnitude of marine biodiversity. In: Duarte, C.M. (Ed.). The exploration of marine biodiversity scientific and technological challenges. Bilbao, Fundación BBVA. p. 33-64.

Bouchet, P.; Bary, S.; Héros, V. \& Marani, G. 2016. How many species of molluscs are there in the world's oceans, and who is going to describe them? Memoires du Muséum national d'Histoire naturelle, 208: 9-24. (Héros, V.; Strong, E. \& Bouchet, P. (Eds.). Tropical deep-sea Benthos 29)

Bouchet, P.; Lozouet, P.; Maestrati, P.\& Héros, V. 2002. Assessing the magnitude of species richness in tropical marine environments: exceptionally high numbers of molluscs at a New Caledonia site. Biological Journal of the Linnean Society, 75: 421-436.

Braga, M.S.C.; Salles, R. \& Fonteles-Filho, A.A. 2001. Ictiofauna acompanhante da pesca de camarões com rede-de-arrasto na zona costeira do município de Fortaleza, estado do Ceará, Brasil. Arquivos de Ciências do Mar, 34 49-60.

Branco, J.0. 1999. Biologia do Xiphopenaeus kroyeri (Heller, 1862) (Decapoda: Penaeidae), análise da fauna acompanhante e das aves marinhas relacionadas a sua pesca, na região de Penha, SC, Brasil. (Doctoral Thesis). São Carlos, SP, Universidade Federal de São Carlos.

Branco, J.0. 2005. Biologia e pesca do camarão sete-barbas Xiphopenaeus kroyeri (Heller) (Crustacea, Penaeidae), na Armação do Itapocoroy, Penha, SC. Revista Brasileira de Zoologia, 22: 1050-1062.

Branco, J.0. \& Fracasso, H.A.A. 2004. Ocorrência e abundância da carcinofauna acompanhante na pesca do camarão sete-barbas, Xiphopenaeus kroyeri Heller (Crustacea, Decapoda), na Armação do Itapocoroy, Penha, Santa Catarina, Brasil. Revista Brasileira de Zoologia, 21: 295-301.

Branco, J.0. \& Verani, J.R. 2006a. Análise quali-quantitativa da ictiofauna acompanhante na pesca do camarão sete-barbas, na Armação do Itapocoroy, Penha, Santa Catarina. Revista Brasileira de Zoologia, 23: 381-391.

Branco, J.0. \& Verani, J.R. 2006b. Pesca do camarão sete-barbas e sua fauna acompanhante, na Armação do Itapocoroy, Penha, SC. In: Branco, J.0 \& Marenzi, A.W.C. (Eds.). Bases ecológicas para um desenvolvimento sustentável: estudos de caso em Penha, SC. Itajaí, UNIVALI. p. 153-170.

Branco, J.0.; Freitas, J.F. \& Christoffersen, M.L. 2015. Bycatch fauna of seabob shrimp trawl fisheries from Santa Catarina State, southern Brazil. Biota Neotropica, 15: e20140143

Castro, I.B.; Braga, A.R.C. \& Rocha-Barreira, C.A. 2005. Altos índices de imposex em Stramonita rustica (Mollusca: Gastropoda) em áreas portuárias dos estados de Alagoas e Sergipe, Brasil. Tropical Oceanography, 33: 123-131.

Colwell, R.K. 2013. EstimateS: Statistical estimation of species richness and shared species from samples. Version 9.1.0. Available at: http://purl.oclc. org/estimates. Access in: 09/07/2019.

Costa, I.D. \& Di Beneditto, A.P.M. 2009. Caracterización preliminar de los invertebrados bentónicos capturados accidentalmente en la pesca de camarones en el norte del estado de Río de Janeiro, sudeste de Brasil. Latin American Journal of Aquatic Research, 37(2): 259-264.

De Léo, F.C. \& Pires-Vanin, A.M.S. 2006. Benthic megafauna communities under the influence of the South Atlantic Central Water intrusion onto the Brazilian SE shelf: A comparison between an upwelling and a nonupwelling ecosystem. Journal of Marine Systems, 60: 268-284.

Diaz, M.J.M. \& Puyana, H.M. 1994. Moluscos del Caribe Colombiano: un catálogo ilustrado. Santafé de Bogota, Colciencias; Fundación Natura. $291 \mathrm{p}$.

Graça-Lopes, R. 1996. A pesca do camarão-sete-barbas Xiphopenaeus kroyeri Heller (1862) e sua fauna acompanhante no litoral do Estado de São Paulo. (Doctoral Thesis). Universidade Estadual Paulista, São Paulo.

Graça-Lopes, R.; Tomás, A.R.G.; Tutui, S.L.S.; Severino Rodrigues, E. \& Puzzi, A. 2002a. Fauna acompanhante da pesca camaroeira no litoral do estado de São Paulo, Brasil. Boletim do Instituto de Pesca, 28: 173-188.

Graça-Lopes, R.; Puzzi, A.; Severino-Rodrigues, E.; Bartolotto, A.S.; Guerra, D.S.F. \& Figueiredo, K.T.B. 2002b. Comparação entre a produção de camarão-sete-barbas e de fauna acompanhante pela frota-de-pequenoporte sediada na praia de Perequê, Estado de São Paulo, Brasil. Boletim do Instituto de Pesca, São Paulo, 28: 189-194.

Guimarães, C.R.P. 2010. Estrutura e dinâmica dos sedimentos superficiais e da fauna bêntica na plataforma continental de Sergipe (Doctoral Thesis). Salvador, Universidade Federal da Bahia.

Guimarães, C.R.P. \& Landim, M.F. 2017. Plataforma continental de Sergipe: caracterização, usos e prognósticos. In: Crestana, S.; Castellano, E.G. \& Rossi, A. (Eds.). Bens e recursos ambientais e o direito ambiental. Brasília, Embrapa. p. 811-826.

Komoroske, L.M. \& Lewison, R.L. 2015. Addressing fisheries bycatch in a changing world. Frontiers in Marine Science, 2: 1-11.

Lemos Júnior, I.C. 2011. Distribuição e aspectos tafonômicos de foraminíferos recentes na plataforma continental de Sergipe, Brasil (Masters Dissertation). Salvador, Universidade Federal da Bahia.

Lemos Júnior, I.C.; Machado, A.J.; Andrade, E.J.; Vieira, F.S. \& Guimarães, C.R.P. 2014. Macroforaminíferos da plataforma continental de Sergipe, Brasil. Scientia Plena, 10: 1-11.

Lewison, R.L.; Crowder, L.B.; Read, A.J. \& Freeman, S.A. 2004. Understanding impacts of fisheries bycatch on marine megafauna. Trends in Ecology \& Evolution, 19: 598-604.

Lima, G.C. \& Couto, E.C.G. 2001. Malacofauna da costa Sergipana: Classe Polyplacophora Blainwille, 1816; Classe Scaphoda Bronn, 1862 e Classe Cephalopoda Cuvier, 1798. Revista Nordestina de Biologia, 15: 91-98.

Lima, S.F.B.; Júnior, I.C.L.; Guimarães, C.R.P. \& Dominguez, J.M.L. 2016. New deep ocean Iravadiidae of the genus Ceratia (Caenogastropoda: Truncatelloidea) from an underwater canyon and adjacent regions of the southwestern Atlantic (northeastern Brazil). Zootaxa, 4066: 183-188.

Lopes, R.G. 1996. A pesca do camarão-sete-barbas Xiphopenaeus kroyeri Heller (1862) e sua fauna acompanhante no litoral do estado de São Paulo (Doctoral Thesis). São Paulo, Universidade Estadual Paulista.

Maia, B.P.; Nunes, Z.M.P.; Holanda, F.C.A.F.; Silva, V.H.S. \& Silva, B.B. 2016. Gradiente latitudinal da beta diversidade da fauna acompanhante das pescarias industriais de camarões marinhos da costa Norte do Brasil. Biota Amazônia, 6: 31-39.

Mendonça, J.T. \& Barbieri, E. 2000. A pesca do camarão-sete-barbas Xiphopenaeus kroyeri no município de Cananéia, SP entre 1998 e 1999. Notas técnicas da FACIMAR, 4: 77-90.

Öndes, F.; Kaiser, M. \& Murray, L. 2018. Fish and invertebrate by-catch in the crab pot fishery in the Isle of Man, Irish Sea. Journal of the Marine Biological Association of the United Kingdom, 98: 2099-2111.

Pacule, H. \& Baltazar, L. 1995. A fauna acompanhante de camarão no banco de Sofala: análise preliminar. Revista de Investigação Pesqueira, 20: 79-95. 
Paiva, M.P.; Menezes, A.A.S. \& Andrade-Tubino, M.F. 2001. Pescarias industriais do camarão-rosa e da fauna acompanhante no estado do Rio de Janeiro, Brasil (1993-1997). Arquivos de Ciências do Mar, 34: 61-66.

Paiva-Filho, A.M. \& Schmiegelow, J.M.M. 1986. Estudo sobre a Ictiofauna acompanhante da pesca do camarão sete-barbas (Xiphopenaeus kroyeri) nas proximidades da Baia de Santos, SP. Aspectos quantitativos. Boletim do Instituto Oceanográfico, 34: 79-85.

Pires-Vanin, A.M.S. 1992. Structure and dynamics of benthic megafauna on the continental shelf offshore of Ubatuba, southeastern Brazil. Marine Ecology Progress Series, 86: 63-76.

Prabhu, P.; Balasubramanian, U. \& Purushothaman, S. 2013. Diversity of Invertebrate trawl by catch off Mallipattinam, Sathubavasatherum, Memesal, southeast coast of India. Advances in Applied Science Research, 4: 249-255.

Redfern, C. 2013. Bahamian Seashells: 1161 species from Abaco, Bahamas. Florida, Bahamianseashells.com Inc.

Riestra, G.; Lozoya, J.P.; Fabiano, G.; Santana, 0. \& Carrizo, D. 2006. Benthic macroinvertebrate bycatch in the snail Zidona dufresnei (Donovan) fishery from the Uruguayan continental shelf. Pan-American Journal of Aquatic Sciences, 1: 104-113.

Rios, E.C. 2009. Compendium of Brazilian sea shells. Rio Grande, Evangraf.

Rodrigues, L.F.; Boos, H. \& Branco, J.0. 2015. Biologia e pesca do camarão sete-barbas (Xiphopenaeus kroyeri, Heller 1862) no Balneário Barra do Sul, SC. Revista CEPSUL, 4: 46-57.

Rueda, J.L.; Gofas, S.; Urra, J. \& Salas, C. 2009. A highly diverse molluscan assemblage associated with eelgrass beds (Zostera marina L.) in the Alboran Sea: Micro-habitat preference, feeding guilds and biogeographical distribution. Scientia Marina, 73: 679-700.
Santos, M.C.F. \& Silva, C.G.M. 2008. Aspectos biológicos do camarão setebarbas, Xiphopenaeus kroyeri (Heller, 1862) (Crustacea, Decapoda, Penaeidae), no município de Caravelas (Bahia, Brasil). Boletim TécnicoCientífico do CEPENE, 16: 85-97.

Santos, M.C.F.; Pereira, J.Á. \& Ivo, C.T.C. 2006. A pesca do camarão branco Litopenaeus schmitti (Burkenroad, 1936) (Crustacea, Decapoda, Penaeidae) no nordeste do Brasil. Boletim Técnico-Científico do (EPENE, 14:33-58.

Santos, M.C.F.; Silva, K.C.A. \& Cintra, I.H.A. 2016. Carcinofauna acompanhante da pesca artesanal do camarão-sete-barbas ao largo da foz do rio São Francisco (Alagoas e Sergipe, Brasil). Acta of Fisheries and Aquatic Resources, 4: 1-10.

Sedrez, M.C.; Branco, J.0.; Júnior, F.F.; Monteiro, H.S. \& Barbieri, E. 2013. Ictiofauna acompanhante na pesca artesanal do camarão sete-barbas (Xiphopenaeus kroyeri) no litoral sul do Brasil. Biota Neotropica, 13: 165-175.

Silva, C.N.S.; Broadhurst, M.K.; Medeiros, R.P. \& Guanais, J.H.D.G. 2013. Resolving environmental issues in the southern Brazilian artisanal penaeid-trawl fishery through adaptive co-management. Marine Policy, 42: 133-141.

The IUCN Red List of Threatened Species. 2018. Version 2017-3. Available at: http://www.iucnredlist.org. Access in: 14/05/2018.

Tunnell Jr., J.W.; Andrews, J.; Barrera, N.C. \& Moretzsohn, F. 2010. Encyclopedia of Texas Seashells: Identification, Ecology, Distribution, and History Natural History. Texas, College Station, Texas A \& M University Press. 